\title{
Investigating Preschool and Primary School Teachers' Self-Efficacy and Needs in Teaching Science: A Pilot Study
}

Susanne Walan ${ }^{1}$ and Shu-Nu Chang Rundgren ${ }^{\star 2}$

$\approx$ In recent years, the curricula reforms at the levels of preschool and primary school in Sweden have caused new demands on the teachers. In particular, numerous teachers lack the educational training in science subjects. Therefore, this study aims to investigate teachers' self-efficacy and needs in relation to science teaching. A total of 71 teachers, divided into three groups of preschool, 1-3 grades and 4-6 grades, were invited to join this pilot study. From the $\mathrm{EU} \mathrm{FP}_{7}$ project, PROFILES, a Likert scale questionnaire (with scores from 1 to 3 to represent strongly disagree, agree to strongly agree, and I don't know was scored o) was used and revised for the data collection in this pilot study. The results showed that the participating teachers had relatively high self-efficacy and no significant differences were found among the three groups of teachers. However, even though the teachers had high self-efficacy, the needs of further education were expressed by the teachers to a large extent. In particular, the group of preschool teachers addressed the need for more content knowledge $(\mathrm{CK})$ in physics and chemistry (>41\%). In terms of the groups of 1-3 and 4-6 grades teachers, the needs relating to scientific literacy were revealed, with a focus on engaging students in socio-scientific problems $(52 \%, 56 \%)$ and assessment $(44 \%, 61 \%)$. The implication of this study is discussed in the hope to contribute to teachers' professional development for both pre- and in-service teachers in science education.

Keywords: Preschool, Primary school, Science, Self-efficacy, Teacher's need 


\section{Preučevanje učiteljeve samoučinkovitosti in učiteljevih potreb pri poučevanju naravoslovja $\mathrm{v}$ predšolskem in osnovnošolskem izobraževanju: pilotna študija}

Susanne Walan in Shu-Nu Chang Rundgren*

$\approx$ V zadnjih letih so učitelji na Švedskem zaradi kurikularnih reform na področju predšolskega in osnovnošolskega izobraževanja postavljeni pred nove zahteve. Konkretneje - veliko učiteljev ima primanjkljaj na področju naravoslovnih predmetov. Namen raziskave je preučiti samoučinkovitost in potrebe učiteljev, povezane s poučevanjem naravoslovja. Vključenih je bilo 71 učiteljev, ki so bili razdeljeni v tri skupine - učitelji v predšolskem obdobju, učitelji, ki poučujejo v prvih treh razredih, in učitelji, ki poučujejo od 4. do 6. razreda. Podatki so bili zbrani s pomočjo vprašalnika Likertovega tipa (od 1 do 3 - se nikakor ne strinjam, se strinjam, se popolnoma strinjam; o - ne vem), ki je bil pripravljen za projekt PROFILES (EU FP 7), in sicer z dopolnitvami za to raziskavo. Izsledki so pokazali, da imajo učitelji, ki so sodelovali, sorazmerno visoko raven samoučinkovitosti, med skupinami pa ni bilo statistično pomembnih razlik. Kljub temu pa je bila potreba po nadaljnjem izobraževanju močno izražena. Podrobneje - predšolski učitelji so izrazili potrebo po več strokovnega znanja na področju fizike in kemije (> $41 \%)$. V drugih dveh skupinah se je potreba pokazala pri vsebinah, povezanih $\mathrm{z}$ naravoslovno pismenostjo: vključevanje učencev $\mathrm{v}$ družbeno-naravoslovno problematiko (52 \%, $56 \%)$ in vrednotenje (44\%, $61 \%$ ). Uporabnost izsledkov študije je podana $\mathrm{z}$ namenom prispevka k profesionalnemu razvoju študentov in učiteljev naravoslovnega izobraževanja.

Ključne besede: predšolsko obdobje, osnovna šola, naravoslovje, samoučinkovitost, učiteljeve potrebe 


\section{Introduction}

Developing teachers' professional knowledge, which includes content knowledge $(\mathrm{CK})$, pedagogical knowledge $(\mathrm{PK})$ and pedagogical content knowledge (PCK), has been addressed during past decades (e.g. Shulman, 1986; Bergqvist, Drechsler, de Jong, \& Chang Rundgren, 2013). Researchers especially emphasized the role of the teacher as one of the critical factors in relation to students' achievement (e.g. Goodrum, Hackling, \& Rennie, 2001; Hattie, 2008; McKinsey, 2007). In line with the importance of developing teachers' professional knowledge and the importance of the teacher's role, a great need has been identified to improve teachers' CK and PCK in preschool and primary school in Sweden (Nilsson, 2008a, 2008b), especially since there have been recent curriculum reforms for both preschool (Lpfö 98, revised 2010) and primary school (Lgr 11) (Swedish National Agency for Education, 2011a, 2011b). The new primary school curriculum has embedded the perspectives of science education, in which students skills in making socio-scientific decisions has been stressed. Besides, science was treated as one subject in the earlier versions of curricula, but now, science has been divided into biology, chemistry and physics. Accordingly, it was not hard to perceive that the demands on teachers have been increasing in Sweden. Similar situations were also reported in other countries. Researchers found that teachers at 1- to- 6-grade levels, either lacked educational training in science, or had received only a small part of science training in their earlier teacher education programs and this had been shown to reflect in the teachers' low self-efficacy (Appelton, 1995, 2006; Hackling, Peers, \& Prain, 2007; Palmer, 2001; Riggs \& Enochs, 1990; Yates \& Goodrum, 1990).

Based on the above-mentioned important role of teachers and the need for developing teachers' PCK and CK, this study aims to investigate teachers' selfefficacy and needs in science teaching. Preschool to primary school teachers were invited to express their self-efficacy concerning aspects of scientific literacy, the current curriculum at each level and arrangements for a student learning environment in science subjects. A Likert scale instrument, developed by $\mathrm{EU} \mathrm{FP}_{7}$ project, PROFILES (Grant No. 266589), was revised according to the Swedish context and the related educational levels in this study.

\section{Background}

Self-efficacy is defined by Bandura (1993) as a person's belief in an ability to succeed in a particular situation. According to Bandura (1993), self-efficacy determines how people feel, think, behave and motivate themselves, and 
he also indicates that individuals with a strong sense of self-efficacy can view difficult tasks as challenges and try to deal with the difficult tasks rather than avoid them. He also claims that there is a marked difference between possessing knowledge and skills and being able to use them well. It means that even if people have the same knowledge and skills, they may perform differently, depending on their self-efficacy (Bandura, 1993). According to Bandura (1993), self-efficacy is mainly about teachers' beliefs in how they can motivate themselves in promoting students' learning.

In the literature, numerous researchers discuss teachers' confidence (e.g. Anderson, Bartholomew, \& Moeed, 2009; Harlen \& Holroyd, 1997; Nilsson, 2008a), but no definitions are put forward to differentiate the concepts of self-efficacy, self-confidence, or confidence. However, Hackling and colleagues (2007), in their study, evaluate primary teachers' confidence and selfefficacy. According to Hackling (an e-mail communication dated 2013-08-27), self-efficacy is a belief about the effectiveness of teaching, whilst confidence for teaching science is a more general attitude and disposition towards teaching science. In this study, we see self-efficacy as competence and confidence defined by PROFILES project and we tested teachers' beliefs about the effectiveness of their organization while teaching science, which is also in line with Hackling's point of view. Also, we want to reveal how teachers feel, think, behave and motivate their science teaching, based on the definition presented by Bandura (1993), not simple as a general attitude.

\section{The curricula reforms for preschool and primary school and the influence on teachers}

In 2010, the Swedish curriculum for preschool education was revised (Swedish National Agency for Education, 2011a). The revision introduced goals of embedding science and technology at preschool level. Since the earlier teacher education programs for preschool teachers did not include science as a compulsory part, current in-service teachers might be expected with the lack of educational training associated with science subjects (i.e. Biology, Chemistry and Physics) and hence a professional development might be needed. This situation is not unique to Sweden. In Australia and New Zealand, research shows that preschool teachers' lacked scientific knowledge, which has caused a great impact on the degree of science content included in the teaching in preschools (Fleer, 2009; Garbett, 2003).

Roehring, Dubosarsky, Mason, Carlson and Murphy (2011) claim that science is often avoided during early childhood education. For example, in 
their study, the reasons provided by early childhood teachers for the exclusion of science were: teachers' own science anxiety and their low self-efficacy with respect to teaching science. The same phenomenon was reported by Greenfield and his colleagues (2009). There was a concern on how to tackle this problem? Yoo (2011) indicated that science teachers at the early childhood stage needed to develop positive attitudes toward science teaching and enhance their practical knowledge so that science could be brought into the classroom. Gropen, ClarkChiarelli, Chalufour, Hoisington and Eggers-Pierola (2009) described a threeyear study working with preschool science teachers where they showed that a strong impact was from developing teachers' knowledge and practices towards improving four-year-olds understanding of basic physical science principles. The researchers concluded that successful professional development programs require evaluation at every level, from the teachers' knowledge to their ability of applying the knowledge with children. Yoo (2011) also pointed out that teachers' reflective thinking led to early childhood teachers' empowerment for child development in science education, and at the same time, the teachers changed their attitudes and became more positive toward science teaching. The more positive teachers became towards science teaching, the more they were willing to prepare science materials and understand children's curiosity about scientific phenomena. To conclude, the importance of developing continuous professional development (CPD) programs is recognized to help preschool teachers and to develop their professional knowledge in teaching science and technology.

\section{Curriculum reforms in Sweden}

The Swedish curricula reforms for compulsory school (grade one to nine) (Swedish National Agency for Education, 2011) which occurred in 2011, indicated a similar situation to that with preschool teachers, as the new curricula raised the demands on primary teachers' scientific knowledge and confidence in teaching science, particular since science was not separated into the subjects of biology, chemistry and physics in the pre-1994 curricula. Again, in Sweden, teachers in compulsory schools might lack educational training in science subjects, and that has been discussed as a problem for teachers' professional development internationally. In the study undertaken by Harlen and Holroy (1997) in the UK, it was found that the primary school teachers' lack of confidence in teaching science was sometimes due to lack of knowledge. To tackle this issue, primary teachers' professional development with the focus of CK and PCK were addressed (Anderson et al., 2009; Hackling et al., 2007).

Following the curricula reforms in Sweden and their influences on teachers, this study embedded the common content in the curricula for preschool 
and primary school in a Likert scale questionnaires to investigate teachers' selfefficacy and needs.

\section{Scientific literacy}

Scientific literacy is the goal of science education, but there is no consensus concerning its definition (e.g. Champagne \& Lovitts, 1989; Millar, 2011; Smith, Loughran, Berry, \& Dimitrakopoulos, 2012). The National Science Education Standards (National Research Council, 1996, p. 2), states that "students need to know, understand and be able to be scientifically literate at different grade levels" and connects scientific literacy with learners' everyday experiences, curiosity in the hope that students become able to describe, explain and predict, read about science in popular press, discuss and evaluate information with science content. Later, Roberts (2007), in his review, discussed scientific literacy in terms of two visions. Vision I, the subject matter (nature of science was also addressed), aims to foster content in the scientific disciplines and Vision II addresses to enhance students to function as life-long and responsible participants in their everyday lives (i.e. a science-in-society oriented aspect). No matter the preferred definition for developing students' scientific literacy, Smith and colleagues (2012) argued that teachers' understanding of scientific literacy was of utmost importance and this had not been well addressed in science education research. Smith and colleagues (2012) studied how primary teachers understood scientific literacy and how their scientific literacy understanding developed during discussions and how their teaching was affected. At the beginning of the Smith et al. study, the teachers viewed science as something characterized by experiments and investigations, but the meaning of scientific literacy was, however, unclear, for example, some teachers related it to only the use of scientific language. After participating in the project for two years, new perspectives of scientific literacy emerged among the teachers. Accordingly, based on the crucial role of teacher in relation to students' science learning and light shed on the importance of teachers' understanding of scientific literacy, we include an aspect of scientific literacy (with a focus on the nature of science and science-in-society aspects) in the teachers' self-efficacy and needs questionnaire in this study.

\section{The learning environment}

How to organize the learning environment for the benefit of science teaching and learning has been stressed within PCK (Shulman, 1986) and teachers' self-efficacy (Bandura, 1993). "The task of creating learning environments rests heavily on the talents and self-efficacy of teachers. Evidence indicates 
that classroom atmosphere has been partly determined by teachers' beliefs in their instructional efficacy" (Bandura, 1993, p. 140). To date, research has shown that the influences of learning environment are especially important in science, compared to other subjects (e.g. Haworth, Kovas, Dale, \& Plomin, 2008). Teacher-student and student-student interactions in the learning environment have also been of interest in science education research (Haworth et al., 2012). Hence, to investigate teachers' self-efficacy and their needs for their further education, the aspect of leaning environment could not be avoidable and should be included in our questionnaire survey in this study.

\section{Aim and research questions}

The aim of this study is to contribute to the development of the CPD program, by exploring with the help of PROFILES, in-service teachers' selfefficacy and needs in science teaching at the preschool to primary school levels. The research questions are:

1. What self-efficacy needs related to the teaching of science are expressed by in-service teachers?

2. Are there differences in self-efficacy and needs among in-service teachers related to the teaching of science at the different levels of preschool, 1-3 grade and 4-6 grade?

\section{Method}

\section{The participants}

A total of 71 in-service teachers from preschool (22 teachers) and primary schools ( 27 grade 1-3 teachers and 22 grade $4-6$ teachers) were invited to participate in this study. The majority of the participating teachers were women; only one male teacher was teaching in grade 1-3 and five male teachers were teaching in grade $4-6$. The participating teachers were all involved in a university networking project started in 2004, in a mid-size region, located in the middle-south of Sweden. The participants joined this project voluntarily and the data were treated anonymously. Details of the teachers' backgrounds are shown in Table 1. 
Table 1. The participants' teaching experiences and educational backgrounds in science.

\begin{tabular}{|l|c|c|c|c|c|c|c|}
\hline $\begin{array}{l}\text { Teaching } \\
\text { experiences }\end{array}$ & $\begin{array}{c}\text { Preschool } \\
(\mathrm{N}=\mathbf{2 2})\end{array}$ & $\begin{array}{c}\text { Grade } \\
1-3 \\
(\mathrm{~N}=27)\end{array}$ & $\begin{array}{c}\text { Grade } \\
4-6 \\
(\mathrm{~N}=22)\end{array}$ & $\begin{array}{c}\text { Education } \\
\text { in science } \\
\text { subjects } \\
(8 \text { hours/ } \\
\text { week })\end{array}$ & $\begin{array}{c}\text { Preschool } \\
(\mathrm{N}=22)\end{array}$ & $\begin{array}{c}\text { Grade } \\
1-3 \\
(\mathrm{~N}=27)\end{array}$ & $\begin{array}{c}\text { Grade } \\
4-6 \\
(\mathrm{~N}=22)\end{array}$ \\
\hline$<1$ year & & 1 & & None & 12 & 6 & 1 \\
\hline $1-5$ years & 2 & 5 & 4 & 5 weeks & 3 & 12 & 3 \\
\hline $6-10$ years & 1 & 5 & 4 & 10 weeks & 1 & 1 & 4 \\
\hline$>10$ years & 19 & 16 & 14 & $>10$ weeks & 6 & 8 & 14 \\
\hline
\end{tabular}

\section{The instrument}

The Likert scale questionnaires used in this study were revised based on the PROFILES project aiming to fit the aims of the Swedish Curricula for preschool (Lpfö98, revised 2010) and compulsory school (Lgr 11) (Swedish National Agency for Education, 2011a, 2011b). In PROFILES, the self-efficacy was relate to nine key areas of motivation, scientific and technological literacy, goals of education, inquirybased science education, nature of science, class environment, assessment, education theories and self-reflection with a total of 50 items. However, after considering the practical issue (i.e. teachers' limited time in answering the questionnaire) and teachers' understanding of the items shown in the PROFILES questionnaire, we decided to provide only three main sections to compose the questionnaires. The three sections were re-named as scientific literacy, curriculum and learning environment and the three sections were decided after interviewing two schools teachers and science educators. These three main sections were also strongly linked to the development of teachers' professional development programs later.

The scale ranges from 1 (strongly disagree) to 3 (strongly agree). Minor changes were made to the different versions of the questionnaire for collecting data in different groups (preschool, grade 1-3 and grade 4-6) of teachers. For example, the word, 'children', in the preschool questionnaire was changed to the word, 'students', in the questionnaire sent to teachers in primary schools. The questions in the category concerning curricula were changed according to the curricula for preschool and primary school as well as the different emphasis on science education. And since assessment is a new part of compulsory school, a question about self-efficacy and needs concerning how to develop assessment instruments in science was added to the questionnaire the questionnaire for primary school. The teachers' backgrounds concerning their education in science subjects and teaching experiences were also collected through the questionnaire survey. The questions for pre-school (16 tiems) and primary school (13 items) teachers were as presented below. 


\section{Questions for pre-school teachers}

\begin{tabular}{ll}
\hline Category & Items \\
\hline 1. I can explain to children that science cannot provide complete \\
answers to all questions. \\
2. I can explain to children how scientists work. \\
3. I use/can include a social orientation to problems working with \\
children in science. \\
4. I can guide the children to think creatively and justify the socio- \\
scientific problems. \\
5. I can realize the general objectives of education within science \\
teaching in pre-school. \\
6. I can specify objectives for activities in preschool that develops \\
children's knowledge and skills in science. \\
7. I can guide the children to develop interest and understanding for circles \\
in nature and how humans, nature and society affect each other. \\
8. I can guide the children to become acquainted with common plants \\
and animals. \\
9. I can guide the children to develop understanding and knowledge \\
about simple chemical and physical processes. \\
10. I can guide the children to develop their ability to identify, investi- \\
gate, document, ask questions about and discuss science. \\
11. I can implement children centered work/teaching at pre-school. \\
12. I can consider children's prior knowledge. \\
13. I can promote the children's communication skills. \\
14. I can promote peer-peer learning through children working in groups. \\
15. I can involve the children in learning through experiments, discus- \\
sions and play. \\
16. I can provide suitable positive feed-back to help the children to un- \\
derstand science according to the curriculum Lpfö 98 revised in 2010.
\end{tabular}

\section{Questions for primary school teachers}

\begin{tabular}{ll}
\hline Category & Items \\
\hline 1. I can explain to students that science cannot provide complete \\
answers to all questions. \\
2. I can explain to students how scientists work. \\
3. I use/can include a social orientation to problems working with \\
students in science. \\
4. I can guide the students to think creatively and justify the socio- \\
scientific problems. \\
5. I can support students when it comes to reaching the objectives of \\
the compulsory school curriculum in chemistry. \\
6. I can support students when it comes to reaching the objectives of \\
the compulsory school curriculum in physics. \\
7. I can support students when it comes to reaching the objectives of \\
the compulsory school curriculum in biology. \\
8. I can guide the students to develop their ability to identify, investi- \\
gate, document, ask questions about and discuss science.
\end{tabular}




\section{Data collection and analysis}

An on-line survey was developed and the link was sent to the participants in the university networking project by email. The data were analyzed by a statistical programme, SPSS software (version 12). The one-way ANOVA analytical method was conducted to compare the answers from the different groups of teachers. The reliability (Cronbach Alpha) was 0.75 .

\section{Results}

The results showed that the preschool teachers had the highest self-efficacy among the three groups of teachers concerning the category of learning environment (Mean=2.32, $\mathrm{SD}=0.42)$ and curriculum (Mean=2.17, $\mathrm{SD}=0.12)$ (Figure 1). The self-efficacy regarding scientific literacy had similar values among the three groups of teachers. There was no significant difference $(p<0.05)$ found among the above-mentioned categories and the three groups of teachers. The highest need for further education was found in the group of 1-3 grade teachers concerning the category of scientific literacy (Mean=2.27, $\mathrm{SD}=0.55$ ) (Figure 2). Again, there was no significant difference $(p<0.05)$ among the three groups of teachers concerning the needs in any of the categories.

Investigating the teachers' self-efficacy and needs in depth in each item addressed in the questionnaire, the preschool teachers expressed their need for further education in physics and chemistry to a high degree $(>41 \%)$. Within the curriculum category, the need to know how to guide the children to develop their ability to identify, investigate, document, ask questions about and discuss science was addressed highly by $49 \%$ teachers. Also $41 \%$ preschool teachers also showed the need on how to guide the children to think creatively and justify the socio-scientific problems (connected to the category of scientific literacy) to a high degree.

There were 56\% 1-3 grade teachers who presented the need concerning how to engage students in socio-scientific problems. In addition, 44\% 1-3 grade teachers indicated the need for further education in how to work with assessment in science. The 4-6 grade teachers pointed out their need in learning how to develop assessments to a high degree $(61 \%)$ and how to work with socioscientific problems in their science teaching was approximately $52 \%$. 


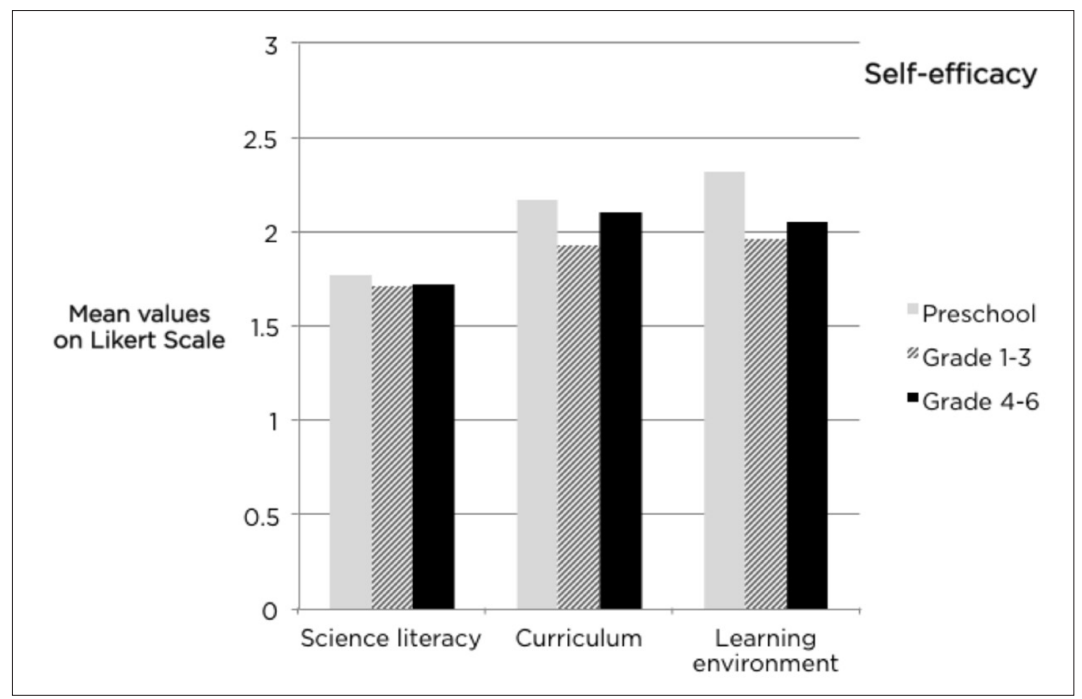

Figure 1. Teachers' self-efficacy in teaching science.

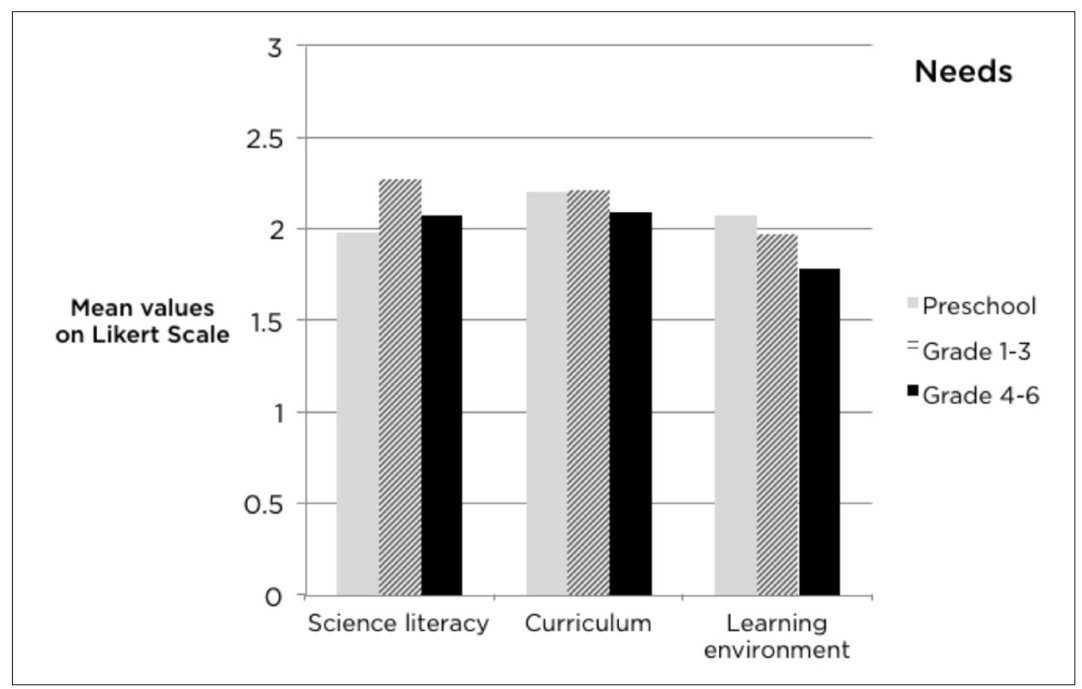

Figure 2. Teachers' needs in science teaching.

\section{Conclusion and Discussions}

Following the curricula reforms for preschool and primary school in Sweden (Swedish National Agency for Education, 2011a, 2011b), there was a new demand on teachers' CK and PCK in science subjects. Research showed that the 
lack of subject knowledge could influence science teachers' teaching and might cause low self-efficacy (Appelton, 1995, 2006; Hackling, Peers, \& Prain, 2007; Palmer, 2001; Riggs \& Enochs, 1990; Yates \& Goodrum, 1990). In line with the importance of developing teachers' CK/PCK and the related CPD programs (Nilsson, 2008a, 2008b) while facing the curriculum reform, this study aims to investigate in-service teachers' self-efficacy and needs concerning scientific literacy, curricula and learning environment. The results of this study were expected to contribute to the development of a CPD program in the near future.

The results from this pilot study (with 71 participating teachers) showed that there was no significant difference $(p<0.05)$ among the three groups of teachers concerning their self-efficacy and needs. From our results, we discovered that the participating teachers had generally high self-efficacy (mean score was over 1.5), but still, the needs for further education were addressed to a high degree (also, mean score was over 1.5). The group of preschool teachers expressed their highest need for further education in $\mathrm{CK}$, specifically in physics and chemistry, which was not surprising, because more than half of the participating teachers (55\%) did not have any earlier educational training in science subjects (Table 1). In despite of this, their self-efficacy was not low. An explanation for this could be that most of the teachers in this group have taught in schools for many years and felt secure in their roles as preschool teachers. Harlen and Holroyd (2007) claimed that education backgrounds and years of teaching experience both played important roles in teachers' confidence.

Many of the primary school teachers (86\%) had undertaken at least 40 hour of education in science and most of them had teaching experiences for more than 4 years (Table 1). Compared to earlier studies, our findings showed that the participating teachers generally had quite high self-efficacy, even though their educational backgrounds lacked science training. How could this be explained? It might be the long teaching experiences making teachers have high self-efficacy. But another explanation could be that the teachers were invited from the university networking project, which had been running since 2004 . Within the network, the teachers had been offered to participate in workshops twice a year. Workshops had included lectures, practical exercises and discussions on science and technology. Many of the participating teachers had participated in those activities, especially the preschool teachers. So, in some way, the participating teachers in this study had gained education during the past years, even though it had not been considered as courses with credit points.

According to Smith et al. (2013), exploring contemporary issues and events made classes more meaningful for both teachers themselves and their students, and moreover, teachers constructed a meaning for scientific literacy 
in a more personally relevant and evident way in their classroom practice, which also made teachers feel more self-confident. Dolan and colleagues (2009) claimed that socio-scientific issue (SSI) could be used to enhance scientific literacy in the fifth grade. SSI teaching strategies have shown positively impact on students' learning based on a multidimensional approach to learn science concepts and SSI containing elements of the real world (e.g. Chang Rundgren \& Rundgren, 2010; Chang Rundgren, 2011). In our findings, both the groups of 1-3 and 4-6 grades teachers indicated the high need for further education in dealing with socio-scientific-oriented teaching. Linking to SSI research in science education, this was not a surprise, since SSI was something new for teachers, especially in primary schools (Dolan et al., 2009). Also, SSI are complex issues (e.g. Chang Rundgren \& Rundgren, 2010) and co-teaching with teachers from difference subject areas was discussed as a way out (Chang Rundgren, 2011), which needs to be developed in CPD more.

Several studies have shown that preschool and primary school teachers need further education in science (e.g. Appelton, 2003; Harlen \& Holroyd, 2007; Nilsson, 2008b; Palmer, 2006). Most of the above researchers also addressed explicitly that teachers needed both CK and PCK. In a study carried out by Morgan (2012), teachers expressed the need for more opportunities to engage with each other to discuss science teaching science teaching and to improve their scientific literacy and teaching skills, which gave them more confidence to teach science. Smith and colleagues (2011) suggested: "A greater sense of self-confidence in science teaching emerged for primary teachers in their project, as a consequence of engaging in more meaningful ways with the derived sense of scientific literacy through a form of scaffolding that occurred through a multi-domain approach" (p. 147). Concerning the learning environment, the preschool teachers in our study had their highest need for further education in how to involve the children in learning through experiments, discussions and play. They also addressed the needs on how to provide suitable positive feed-back to help the children understand science according to the curriculum. There was also a need among 4-6 grade teachers for further education concerning assessment. This was reflected as an expectation by the Swedish National Agency for Education. According to the new reform, teachers in grade six were required to give grades to their students from December 2012 onwards (Swedish National Agency for Education, 2013). The primary school teachers wanted more education regarding how to implement student-centered work/teaching in the classroom. All of these questions were considered as part of PCK.

Based on this pilot study, we showed that the Likert scale instrument used in this study was feasible (reliability $=0.75$; time cost reasonable) as a 
pre-survey before conducting CPD programs for science teachers at preschool and primary school levels. Even though there was no significant difference among groups of teachers, teachers were shown to possess different needs for preschool and primary school, which could be used for the development of a suitable CPD in the coming future. Reliability of the data could be raised using a bigger sample size of teachers from different regions in Sweden so as to provide a bigger picture of teachers' self-efficacy and needs in Sweden nationally. A comparative study with other countries would be of importance as well, due to the globalization age.

\section{References}

Anderson, D., Bartholomew, R., \& Moeed, A. (2009). Confidence, Knowledge and Teaching Strategies: A Study of Pre-service Science teachers in a New Zealand University. Paper presented at the British Educational Research Association Annual Conference, University of Manchester, 2-5 September 2009.

Appelton, K. (1995). Student teachers' confidence to teach science: Is more science knowledge necessary to improve self-confidence? International Journal of Science Education, 19, 357-369. Appelton, K. (2003). How Do Beginning Primary School Teachers Cope with Science? Toward an Understanding of Science Teaching Practice. Research in Science Education, 33, 1-25.

Appelton, K. (2006). Science Pedagogical Content Knowledge and Elementary School Teachers. In K. Appelton (Ed.), Elementary Science Teacher Education (pp. 31-54). New Jersey: Lawrence Erlbaum Associates, Inc., Publishers.

Bandura, A. (1993). Perceived Self-Efficacy in Cognitive Development and Functioning. Educational Psychologist, 28(2), 117-148.

Bergqvist, A., Drechsler, M., de Jong, O., \& Chang Rundgren, S. N. (2013). Representations of chemical bonding models in school textbooks - help or hindrance for understanding? Chemistry Education Research and Practice, 14, 589-606.

Champagne, A. B., \& Lovitts, B. E. (1989). Scientific literacy: A concept in search of definition. In A.

B. Champagne, B. E. Lovitts, \& B. J. Callinger (Eds.), This year in school science. Scientific literacy (pp. 1-14). Washington, DC: AAAS.

Chang Rundgren, S. N. (2011). Post it! - A cross-disciplinary approach to teach socioscientific issues. Teaching Science, 5(3), 25-28.

Chang Rundgren, S. N., \& Rundgren, C.-J. (2010). SEE-SEP: From a separate to a holistic view of socioscientific issues. Asia-Pacific Forum on Science Learning and Teaching, 11(1), Article 2.

Dolan, T. J., Nichols, B. H., \& Zeidler, D. L. (2009). Using Socioscientific Issues in Primary

Classrooms. Journal of Elementary Science Education, 21(3), 1-12.

Fleer, M. (2009). Supporting scientific conceptual consciousness of learning in a "roundabout way" in play-based contexts. International Journal of Science Education, 31(8), 1069-1089. 
Garbett, D. (2003). Science education in early childhood teacher education: Putting forward a case to enhance student teachers' confidence and competence. Research in Science Education, 3, 467-481. Goodrum, D., Hackling, M., \& Rennie, L. (2001). The status and quality of teaching and learning of science in Australian schools. Canberra, ACT: Department of Education, Training and Youth Affairs. Greenfield, D. B., Jirout, J., Dominguez, X., Greenberg, A., Maier, M., \& Fuccillo, J. (2009). Science in the Preschool Classroom: A Programmatic Research Agenda to Improve Science Readiness. Early Education and Development, 2o(2), 238-264.

Gropen, J., Clark-Chiarelli, N., Chalufour, I., Hoisington, C., \& Eggers-Pierola, C. (2009). Creating a Successful Professional Development Program in Science for Head Start Teachers and Children: Understanding the Relationship between Development, Intervention and Evaluation. Society for Research on Educational Effectiveness.

Hackling, M., Peers, S., \& Prain, V. (2007). Primary Connections: Reforming science teaching science in Australian primary schools. Teaching Science, 53(3), 12-16.

Haworth, C. M. A., Kovas, Y., Dale, P. S., \& Plomin, R. (2008). Science in elementary school:

Generalist genes and school environments. Intelligence, 36, 694-701.

Haworth, C. M. A., Davis, O. S. P., Hanscombe, K. B., Kovas, Y., Dale, P. S., \& Plomin, R. (2012).

Understanding the science learning environment: A genetically sensitive approach. Learning and Individual Differences, 23, 145-150.

Harlen, W., \& Holroy, C. (1997). Primary teachers' understanding of concepts of science: Impact on confidence and teaching. International Journal of Science Education, 19, 93-105.

Hattie, J. A. C. (2008). Visible learning: a synthesis of over 800 meta-analyses relating to achievement. London: Routledge.

Karlstad University. (2013). Teknikerjakten. Retrieved September 162013 from www.kau.se/

Teknikerjakten

McKinsey \& Company. (2007). How the world's best performing school systems come out on top.

London. Retrieved September 162013 from http://mckinseyonsociety.com/downloads/reports/

Education/Worlds_School_Systems_Final.pdf

Millar, R. (2011). Twenty First Century Science: Insights from the Design and Implementation of a Scientific Literacy Approach in School Science. International Journal of Science Education, 28(13), 1499-1521.

Millar, R., \& Osborne, J. (1998). Beyound 200o. Science education for the future. London: Nuffield Foundation.

Morgan, A-M. (2012). 'Me as a Science teacher': Responding to a Small Network Survey to Assist teachers with Subject-Specific Literacy Demands in the Middle Years of Schooling. Australian Journal of Teacher Education, 37(6), Article 6.

National Research Council. (1996). National science education standards. Washington, DC: National Academy Press.

Nilsson, P. (2008a). Learning to Teach and Teaching to Learn - Primary science student teachers' complex journey from learners to teachers. Dissertation. Linköping Studies in Science and Technology 
Education No 19.

Nilsson, P. (2008b). Recognizing the needs- Student teachers' learning to teach from teaching.

NorDiNa, 4(1), 284-299.

Palmer, D. H. (2001). Factors contributing to exchange amongst preservice elementary teachers.

Science Education, 86, 122-138.

Palmer, D. (2006). Durability of changes in self-efficacy of preservice primary teachers. International Journal of Science Education, 28(6), 655-671.

PROFILES. (2013). Retrieved November 52013 from http://www.profiles-project.eu/

Riggs, I., \& Enochs, L. (1990). Towards the development of an elementary teacher's science teaching efficacy belief instrument. Science Education, 74, 625-637.

Roberts, D. A. (2007). Scientific literacy/science literacy. In S. K. Abell \& N. G. Lederman (Eds.),

Handbook of research on science education (pp. 729-780). Mahwah, NJ: Lawrence Erlbaum.

Roehring, G. H., Dubosarsky, M., Mason, A., Carlson, S., \& Murphy, B. (2011). We Look More,

Listen More, Notice More: Impact of Sustained Professional Development on Head Start Teacher's

Inquiry-Based and Culturally-Relevant Science Teaching Practices. Journal of Science Education and Technology, 20(5), 566-578.

Shulman, L. S. (1986). Those Who Understand: Knowledge Growth in Teaching. Educational

Researcher, 15(2), 4-14.

Smith, K. V., Loughran, J., Berry, A., \& Dimitrakopoulos, C. (2011). Developing Scientific Literacy in

a Primary School. International Journal of Science Education, 34(1), 127-152.

Swedish National Agency for Education. (2011a). Curriculum for the compulsory school system, the pre-school class and the leisure-time centre 2011. Stockholm: Swedish National Agency for Education. Swedish National Agency for Education. (2011b). Curriculum for the Preschool Lpfö 98: Revised 2010. Stockholm: Swedish National Agency for Education.

Swedish National Agency for Education. (2013). How does assessment take place? Retrieved November 32013 from http://www.skolverket.se/om-skolverket/andra-sprak-och-lattlast/in-english/ the-swedish-education-system/compulsory-school/about-compulsory-school/how-does-assessmenttake-place-1.87933

Yates, S., \& Goodrum, D. (1990). How confident are primary school teachers in teaching science?

Research in Science Education, 20, 300-305.

Yoo, S-Y. (2011). Early Childhood Teachers' Empowerment and Implementation of Teaching Method Programs for Child Development in Science Education. Education, 130(4), 556-560. 


\section{Biographical note}

SUSANNE WALAN is currently a PhD student in biology education at Karlstad University. In her dissertation, she focuses on context- and inquirybased science teaching in both formal and informal education.

Shu-Nu Chang Rundgren is the professor of science education at Karlstad University. Meanwhile, she is the scientific leader and coordinator of the Center of Science, Mathematics and Engineering Education Research (SMEER) at Karlstad University. Her research interests are teaching and learning socioscientific issues (SSI) and SSI-argumentation, teachers' professional development on context- and inquiry-based science education as well as the public understanding of science and health. 